\title{
ADA APA DENGAN GEOGRAFI MANUSIA?
}

\author{
Oleh: \\ Hastuti \\ Jurusan Pendidikan Geografi, FISE UNY
}

\section{Abstrak}

Geografi mengalami dinamika dalam menggambarkan muka bumi sebagai tempat dan ruang bagi manusia melangsungkan kehidupannya mulai dari identifikasi secara sederhana hingga menggunakan model pencatatan dan sketsa kemudian memanfaatkan alat bantu seperti peta, citra radar, statistik, matematika, dan Sistem Informasi Geografi. Dalam pengembangan geografi sesuai untuk menjelaskan fenomena muka bumi dalam konteks keklnlan selring dengan proses perkembangan ilmu dan teknologi. Geografi sebagai ilmu sintetik tentu saja memandang fenomena geosfer dengan pendekatan keruangan, kelingkungan dan kewilayahan dengan orientasi pada pemecahan masalah sebagai pertimbangan pengambil kebijakan untuk kesejahteraan umat manusia.

Ketika menolak deterministik, geografi meletakkan manusia sebagai faktor litama menawarkan posibilism kemudian probabilisme mengandung unsur hubungan timbal balik antara alam dan manusia dalam struktur, pola dan proses pada tempat dan waktu tertentu di muka bumi kemudian menekankan kajian antropocentris. Antropocentris menekankan manusia sebagai pusat perhatian geografi, ini sebagai awal semakin berkembangnya devisi geografi manusia. Di Indonesia, ketika geografi dikembangkan mulai dari SD sampai perguruan tinggi seolah kurang konsisten karena terbagi dalam devisi terpisah, yaitu dalam ranah ilmu alam dan ranah ilmu humaniora. Perhatian lebih serius masih diperlukan agar geografi manusia dapat memberikan kontribusi pada pengembangan geografi sebagai ilmu dan pemecahan persoalan manusia di muka bumi ini.

Kata kunci: geografi, manusia, geografi manusia

\section{Pendahuluan}

Obj:k studi geografi adalah perbedaan dan persamaan geosfer meliputi alam, manusia dan lingkungannya. Dilihat dari objek studi geografi 
termasuk konsorsium ilmu alam dan sosial. Di Indonesia geografi dikembangkan dalam konsorsium berbeda. Universitas Indonesia (UI) dan Universitas Gajah Mada (UGM) mengembangkan geografi dalarm, konsorsium ilmu alam. Universitas mantan IKIP yang menghasilkan guru geografi sekolah menengah ke bawah, maka geografi dikembangkan di bawah fakultas yang menaungi kajian humaniora. Geografi dalam konsorsium ilmu humaniora menjadi pilihan sebagian universitas mantan IKIP merunut pada orientasi output lembaga pendidikan tinggi. Output sebagai pengajar di sekolah menengah ke bawah tersebut lebih sesuai mengingat geografi secara garis besar di sekolah menengah dan sekolah dasar termasuk dalam rumpun mata pelajaran IPS (IImu Pengetahuan Sosial).

Pada era kemajuan ilmu dan teknologi, perdebatan geografi terus berlangsung mengiringi dinamika perkembangan ilmu. Perdebatan untuk pengembangan geografi agar memiliki kemampuan merespon secara kondusif. Perdebatan diperlukan sepanjang tidak mengancam eksistensi geografi untuk berkontribusi pada pemecahan persoalan kemanusiaan dan peningkatan kesejahteraan umat manusia. Ironisnya di tengah gempitanya ilmu sosial justru gaung geografi manusia kian sayup terdengar. Geografi manusia kurang mendapat perhatian untuk dikembangkan dalam naungan pure science secara mandiri. Untuk perkembangan ilmu masih diperlukan beberapa penunjang disamping mengenai batasan apa yang dikaji, bagaimana cara mempelajarinya, dan sasaran untuk apa dipelajari yakni adanya faktor tokoh pendukung ilmu, adanya pusat pengembangan, dan sarana publikasi (Suharyono, 1994). Yang menjadi pemikiran saat ini mengapa di antara kriteria ini masih kurang mendapat perhatian insan yang selama ini berkecimpung dalam ranah geografi manusia terutama dengan semakin terpuruknya geografi manusia.

\section{Masih Diperlukan Geografi Manusia?}

Geografi dikembangkan oleh beberapa ahli dengan latar belakang ilmu yang bervariasi, sejak Ratzel yang ahli botani, kemudian Sauer dengan latar belakang sosiologi memiliki peluang untuk mengkaji tentang muka bumi, dan kemudian menerbitkan exemplar yang dijadikan acuan pengembangan teori geografi. Ketertarikan para ahli dengan latar belakang disiplin lain biasa terjadi dalam perjalanan pengembangan ilmu. Mengapa harus mengharapkan interest dari ahli disiplin lain bila ahli dengan latar 
belakang disiplin yang sama juga ada, ini terkait dengan semakin kurangnya perhatian untuk kajian dan pengembangan ilmu. Apabila geografi manusia mampu menunjukkan perannya sesuai dengan prinsip-prinsip pengembangan ilmu untuk kemaslahatan manusia maka ilmu akan semakin memiliki keni:scayaan.

Ilmu dapat dibedakan dalam tiga cabang, yakni ilmu alam, ilmu hayat (biologi) dan ilmu sosial (Suriasumantri, 1990). Geografi termasuk dalam ilmu alam dan ilmu sosial. Kesulitan analisis dihadapi geografi dengan objek material yang ada karena masing-masing dikembangkan dengan filosofi dan paradigma yang berbeda terutama ketika terjadinya revolusi kuantitatif. Geografi sebagai ilmu spesifik tentang geosfer dalam kajian ilmu sosial lebih menekankan kegiatan manusia sebagai aspek pokoknya. Konsep ini sesuai dengan 'antropocentris' pada sisi pengembangan pure science geografi yang cenderung ke ilmu alamiah. Dalam pengembangan ilmu dituntut spesialisasi agar ilmu mampu memberikan kontribusi yang semakin berarti dan mendalam, meskipun kerja sama antar berbagai disiplin ilmu sering diperlukan untuk pemecahan berbagai persoalan yang kian kompleks. Geografi tidak perlu lagi hanya berkutat untuk memperdebatkan kedudukan geografi dalam struktur keilmuan, tetapi lebih ditekankan untuk mencari format pengembangan ilmu sebagai ilmu yang spesifik.

Geografi yang diperkenalkan oleh Herodotus, Strabo, Humbolt, Ritter dan Darwin dianggap berpaham "determinis lingkungan (environmental determinism)", menempatkan geografi dengan dikaitkan faktor lokasi dalam hubungannya secara keseluruhan di permukaan bumi. Brunhess yang menolak deterministik, meletakkan manusia sebagai faktor utama karena alam menawarkan kemungkinan yang melahirkan probabilisme mengandung unsur hubungan timbal balik antara alam dan manusia dalam struktur, pola dan proses di muka bumi menurut tempat dan waktu, fokus kajian human emancipation, dan geografi bersifat antropocentris (Johnston, 2000; Peet, 1998; Kitchin dan Tate, 2000).

Geografl manusia seharusnya dapat sejajar dengan ilmu yang memiliki obyek kajian manusia, bahkan lebih unggul karena spesifikasi yang dimiliki. Ahli geografi manusia memiliki kekuatan latar belakang penguasaan informasi fenomena muka bumi secara komprehensif. Sementara itu kehidupan manusia di muka bumi yang muncul sebagai landscape tidak dapat dipisahkan antara unsur manusia dengan alam. Ketajaman berpikir 
derigan penggambaran, penjelasain, analisis tentang feriomena apa, bagaimana, dan mengapa manusia terkait dengan alam menjadi instrumen kekuatan geografi manusia.

Geografi manusia mengkaji secara komprehensif tentang manusia meliputi apa, bagaimana, dan mengapa terkait muka bumi melalui pencatatan, identifikasi, penggambaran, analisis, dan penafsiran. Fenomena landscape kemudian dapat digambarkan dengan melihat lokasi, karakteristik, hubungan, erubahan, dan keunikan yang ada sehingga mampu dibedakan dalam ruang tertentu. Unsur-unsur ruang dengan segala dinamika yang ada berkaitan dengan aspek fisik dan aspek manusia. Melalui kajian geografi diharapkan mampu memahami tentang variasi unsur apa saja yang berada di suatu ruang serta dapat memahami dan menjelaskan tentang hubungan yang ada di masa lalu, masa sekarang dan prediksi masa depan.

Kajian tentang hubungan manusia dengan alam dalam perspektif geografi menjadi penting ketika manusia dengan ilmu dan teknologi mampu menguasai dan memaníaatkan muka bumi untuk kesejahteraannya. Proporsi kajian tentang manusia selayaknya menjadi titik pusat perhatian geografi dengan semakin bervariasinya landscape hasil rekayasa manusia. Ironis baliwa geografi yang mengkaji tentang manusia eksistensinya justru semakin terpinggirkan ketika ilmu sosial semakin berperan dalam pemecahan permasalahan yang dihadapi manusia di muka bumi ini.

Upaya-upaya perlu dilakukan agar geografi manusia dengan kajian manusia sebagai pangkal kajian memiliki kontribusi untuk pengembangan ilmu dan berperan dalam setiap pengambilan keputusan dan perencanaan kebijakan. Kebijakan tersebut terkait dengan pemanfaatan muka bumi untuk kemaslahatan manusia dengan cara pikir yang komprehensif. Agar geografi manusia dapat dimanfaatkan untuk pengembangan, pemahaman, penyadaran, dan pencermatan adanya interaksi, interelasi, interdependensi antara manusia dan alam sehingga terjaga keselarasan, keseimbangan, sinergi, dan kesinambungan di muka bumi melalui ontologi, epistemologi, dan aksiologi perlu adanya dukungan lembaga dan infrastruktur terkait untuk pengembangan ilmu. 


\section{Pasca Revolusl Kuantitatlf dan Pendekatan Geografi Manusia}

Terjadinya revolusi kuantitatif dengan paham positivistik yang banyak digandrungi ilmu alam juga melanda geografi dalam analisisnya ke arah nomothetik. Verifikasi kebenaran pasca revolusi kuantitatif menuntut pembuktian melalui kuantifikasi sehingga geografi dengan objek geosfer sering terjebak di dalamnya (Kitchin dan Tate, 2000). Paparan fenomena geografi dituntut untuk diterjemahkan dalam verifikasi kuantitatif karena pend $: k$ atan kuantitatif dianggap lebih dapat menjelaskan dan menganalisa rangkaian fenomena geosfer meskipun cenderung kurang sesuai apabila harus menjelaskan fenomena antroposfer. Pasca revolusi kuantitatif, model pendekatan kualitatif dianggap kurang sesuai untuk pemaparan dan pemecahan masalah geosfer. Meskipun teori geografi sampai saat ini masih diyakini sebagai sebuah kebenaran, tetapi justru diperoleh dengan model verifikasi kualitatif (Kitchin dan Tate, 2000). Perilaku dan aktifitas manusia tidak seiuruhnya dapat diungkap secara gamblang dengan penjelasan kuantitatit. Hal ini mendorong ilmu yang terkait dengan kajian menusia mulai mengembangkan pendekatan yang diharapkan mampu memberi penjelasan tentang manusia.

Geografi manusia untuk menggambarkan muka bumi dengan paham sistematis, regional, deskriptif dan analitik agar mampu menjawab permasalahan muka bumi yang bervariasi merupakan rangkaian kerja geografi secara ideografik hingga nomotetik (Johnston, 2000). Sebagai ilmu, geografi manusia memiliki ciri keilmuan yang terangkum dalam ontologi, epistemologi dan aksiologi untuk menjawab tentang apa, bagaimana pengembangan ilmunya, dan manfaat yang dapat dikembangkan (Suriasumantri, 1990; Suharyono, 1994). Meskipun masih belum tuntas dalam penerapannya dan mengalami kesulitan, namun ada kesepakatan geografi dengan pendekatan spatial, kelingkungan dan pendekatan kewilayahan (Suharyono, 1994).

Kombinasi pendekatan kuantitatif dan kualitatif dapat dipadukan sesuai dengan objek material geografi yang memadukan antara fenomena alam dan manusia dengan segala peradaban dan perilaku serta aktifitasnya. Upaya menemukan variasi model pendekatan tersebut menjadi tantangan yang perlu mendapat perhatian dalam pengembangan geografi sebagai ilmu yang khas yakni kemampuan memadukan secara selaras antar fenomena geosfer. Geografi dalam rumpun ilmu sosial 
banyak mengembangkan teori sosial meliputi kependudukan, kebudayaan dan perilaku yang menyoroti tentang proses ekonomi, proses sosial, proses politik dan proses psikologi. Dasar pengembangan geografi sebagai ilmu yang menekankan aspek kegiatan manusia di muka bumi dengan aspek geosfer (lithosfer, hidrosfer, atmosfer, biosfer) sebagai tempat kegiatan manusia merupakan wacana kerangka acuan untuk meletakkan geografi sebagai ilmu sosial. Adopsi dan aplikasi teori-teori sosial untuk analisis dan pengembangan geografi diharapkan lebih menguatkan geografi sebagai ilmu sosial. Diharapkan dengan pendekatan khas geografi dapat secara dinamis menjawab persoalan sosial sesuai dinamika yang terjadi pada perkembangan sosial di masyarakat. Geografi bukan dicirikan oleh materi yang dikaji dan pertanyaan tentang apa itu geografi, melainkan oleh cara menjawab pertanyaan (Sutanto, 2000). Bagaimana suatu persoalan dapat dijawab melalui langkah dan pendekatan geografi sehingga dapat memaparkan solusi atas fenomena tersebut akan menjadikan geografi memiliki arti penting. Langkah yang perlu diperhatikan adalah mencari jawaban atas permasalahan yang kian kompleks dengan metode dan pendekatan khas geografi. Dinamika kehidupan manusia di muka bumi merupakan objek studi menarik dan terus berkembang sehingga memerlukan inovasi agar dalam aplikasi dan pengembangan geografi sebagai ilmu sosial dengan tetap berpegang pada metode dan pendekatan geografi tidak mengalami ketertinggalan.

Geografi manusia juga mengenal positivisme untuk memastikan kebenaran sebagai katalisator terjadinya berbagai perubahan tata kerja geografi dengan pengumpulan data serta pengukuran objek material dan pengujian hipotesis memanfaatkan statistik, matematik dan komputer, sistem informasi geografi untuk menjelaskan kausalitas dan verifikasi, bukan sekedar mengidentifikasi muka bumi. Mengenal Humanistik merupakan sumber pengetahuan subyektivitas dan individual dengan menekankan hakekat kebenaran pada pemikiran manusia sesuai dengan aktivitasnya. Pendekatan humanistik menekankan idealisme, pragmatık, fenomenologi dan eksistensialis mengandung makna semua yang ada di muka bumi mempunyai kaitan sebab akibat baik secara langsung ataupun tidak langsung. Teori yang dibangun pada aliran ini merupakan teori yang bersifat subyektif dan mendasarkan pemikiran individu sehingga melahirkan paradigma yang ambigu antara percaya dan tidak percaya 
dengan karakteristik. Pengetahuan tergantung pada penelitian praktis dan bermanfaat serta filsafat mendalam, mengenali dan memahami obyek dasar yengetahuan secara praktis, dan eksistensialis merupakan filsafat dekat dengan faham marxisme memberikan perhatian peran individu dalam kehidupan masyarakat. Pendekatan strukturalis menjelaskan fenomena yang bersifat antropocentris diterapkan dalam kajian ilmu yang bersifat sosiologi mendasarkan bahwa sosiologi membahas fenomenologi manusia sebagai subyek sosial, bukan atas semua obyek di muka bumi. Pendekatan strukturalis dalam geografi memberikan sumbangan penelitian terkait fenomena sosial di suatu tempat, lokasi atau ruang. Dalam membangun teori geografi manusia diperlukan kriteria kebenaran yang utuh, terpadu, benar apabila diuji, fungsional dalam ruang dan waktu, yakni koherensi, korespondensi dan pragmatisme.

Pendekatan kuantitatif realitas tampil dalam kuantitas, sedangkan dalam pendekatan kualitatif realitas akan melahirkan aliran materialisme, idealisme, dan naturalisme. Epistemologi adalah cara memperoleh pengetahuan secara benar yang dapat dilakukan melalui deduktif dan induktif. Kebenaran melalui deduktif rasional yaitu pembenaran yang menarik silogisme dari umum ke hal khusus, dengan landasan teori yang relevan untuk memperoleh jawaban sementara atas suatu kebenaran. Induktif empiris yaitu pembenaran yáng ditarik dari pengalaman yang khusus ke umum. Pembenaran tradisional yaitu koherentisisme atau konsistensi bahwa sesuatu dianggap benar bila mempunyai hubungan dəngan sesuatu terdahulu yang dianggap benar. Di dalam kajian geografi juga dikenal idiografik, nomotetik dan behavioral. Idiografik memperhatikan pada hal yang bersifat khusus dengan cenderung menjelaskan deskriptif. Nomotetik memperhatikan hal yang umum dan berusaha menjelaskan hubungan kausalitas melalui verifikasi. Behavioral memperhatikan hal umum dan berusaha memperkirakan dengan prediksi kuantitatif.

Saat ini kesepakatan tentang pendekatan geografi manusia memanfaatkan pendekatan geografi yang mencirikan kerangka kerja geografi meliputi pendekatan keruangan, kelingkungan dan kewilayahan (Johnston, 2000). Pendekatan keruangan menyangkut pola, proses dan struktur dikaitkan dengan dimensi waktu maka analisisnya bersifat horizontal mellputi; pola dari sebaran gejala tertentu muka buml (Spatlal Pattern), keterkaitan atau hubungan antar gejala (Spatial System), perkembangan 
atau perubahan gejala (Spatial Process). Analisisnya menekankan pada variasi distribusi dan lokasi dari berbagai gejala atau kelompok gejala muka bumi. Faktor yang menyebabkan pola distribusi keruangan berbeda dapat diubah sedemikian rupa sehingga distribusinya menjadi lebih efektif merupakan pangkal kajian geografi.

Geografi dengan pendekatan yang digunakan diharapkan mampu berperan dalam membuat perencanaan dan pengembangan untuk mewujudkan kesejahteraan manusia selaras dengan alam. Dalam lingkup yang luas pendekatan keruangan meliputi proses keruangan, struktur keruangan, pola keruangan, interaksi keruangan, organisasi keruangan, asosiasi keruangan, komparasi keruangan, dan kecenderungan perkembangan keruangan (Yunus, 2005). Pendekatan kelingkungan sebagai studi interaksi antara organisme hidup dengan lingkungan ciisebut sebagai ekologi suatu ekosistem. Interaksi kehidupan manusia dengan faktor fisisnya membentuk sistem keruangan menghubungkan region dengan region lainnya dikaji dalam geografi. Pendekatan kelingkungan adalah metode untuk mendekati, menelaah dan menganalisa suatu gejala atau sesuatu masalah dengan menerapkarı konsep dan prinsip ekologi. Pendekatan ini merupakan analisis hubungan antar variabel manusia dengan variabel lingkungan. Pandangan dan telaah ekologi diarahkan pada hubungan antara manusia sebagai makhluk hidup dengan lingkungan alam, sebagai contoh dalam pendekatan ekologi bahwa suatu pemukiman ditinjau sebagai suatu bentuk ekosistem hasil interaksi penyebaran dan aktivitas manusia dengan lingkungan alamnya. Pendekatan kewilayahan merupakan kombinasi antara analisa keruangan dan analisa kelingkungan sering disebut analisa kompleks wilayah. Karakter geografi menjadi berbeda dengan disiplin ilmu lain yang secara tegas mengelompok pada ilmu yang memfokuskan perhatian pada unsur alain dan kelompok ilmu yang memfokuskan kajian pada manusia dengan segála perilaku dan aktifitasnya. Geografi manusia memfokuskan perhatian pada pola dan proses yang menekankan interaksi manusia dengan lingkungannya (Johnston, 2000).

\section{Tema-Tema Geografi Manusia}

Geografi dalam kajiannya memperhatikan tentang tema-tema ya:ıg dijadikan peđoman untuk mengkaji fenomena muka bumi. Ada lima tema dalam geografi yaitu: areal differentiation, landscape, man-environmeni, 
spatial distribution, dan geometric. Dari lima tema tersebut areal differentiation masih tetap menjadi tema utama dalam penelitian-penelitian geografi. Tema-tema penelitian yang lain sebenarnya merupakan subordinasinya. Tema bentang lahan tetap merupakan tema yang penting, tetapi bukanlah merupakan tema unggulan. Tema ini menjadi tema yang banyak muncul di kalangan geografiwan Amerika khususnya pada kelompok Berkeley school. Kelompok ini memisahkan/membedakan antara bentang lahan alam/fisis dan budaya (physical and cultural landscape), dan kemudian mempelajari interaksi antara keduanya. Sebagaimana yang dikemukakan Haggett (1984), bahwa sebenarnya geografi dapat disebut sebagai ilmu tentang ekologi manusia yang menjelaskan hubungan antara lingkungan fisis dengan distribusi aktivitas manusia. Tekanan pada studi dengan tema manusia-lingkungan adalah terikat. pada wilayah tertentu, sehingga mengarah kepada geografi regional. Tema ini nampaknya banyak disukai terutama dalam rangka studi pengembangan wilayah dengan sebutan lain analisis spasial/keruangan. Ada lima konsep kunci yang berhubungan dengan tema ini yaitu location, distance, space, accessibility, dan spatial interaction. Tema Geometric merupakan tema tertua dibandingkan yang lain, tetapi relatif banyak ditinggalkan. Namun sejak tahun 1950 mulai meningkat, terutama pernyataan yang diberikan oleh Haggett (1984) sehingga tema ini menjadi sangat penting. Pada dasarnya ke lima tema itu, di dalam penelitian geografi saling mengisi, jadi tidak sepenuhnya berdiri sendiri terlepas dari yang lain (exclucive) meskipun tidak menyatu seluruhnya (inclucive). Perlu diketahui, bahwa diantara lima tema tersebut, tema yang pertama banyak digunakan sebagai pangkal tolak penelitian dalam studi geografi. Dapat dijelaskan mengenai dua konsep yang menjadi perhatian geografi, pertama tentang bagaimana (how) kita harus melakukan dalam mempelajari fenomena, khususnya untuk operasionalisasi mengenai deskripsi dan eksplanasi. Kedua tentang apa (what) yang harus dipelajari; hal ini memberi identifikasi wilayah (domain) objek dan peristiwa-peristiwa (events) bagaimana deskripsi dan explanasi harus dilakukan. Bila konsep pertama merupakan metode dalam geografi, konsep kedua adalah sasaran atau objek substantif studi geografi.

Areal Differentiation (AD) atau Diferensiasi Area (DA) dapat diartikan perbedaan antar area. Perbedaan area dengan region, sering digunakan 
secara timba! balik, tetapi berbeda esensi. Bahwa area maupun region samasama merupakan bagian permukaan bumi yang mungkin luas atau sangat luas (misal benua) atau mungkin sempit bahkan sangat sempit (dusun, rukun tetangga, padang gembala). Pengertian area terkait dengan studi geografi tidak memerlukan kriteria khusus seperti region untuk membedakan dengan bagian permukaan bumi di sekitarnya. Baik area maupun region mempunyai batas-batas tertentu berupa batas alam maupun batas buatan yang ditentukan sesuai dengan kepentingan. Jika batas alam dapat dilihat di lapangan. batas buatan hanya dapat diamati dalam peta. Wilayah dihampiri dengan pengertian "areal differentiation" yaitu interaksi antar wilayah akan berkembang karena pada hakekatnya berbeda antara wilayah satu dengan wilayah lainnya. Penyebaran fenomena tertentu (analisa keruangan) dan interaksi antara variabel manusia dan lingkungannya dengan analisa kelingkungan menjadi perhatian pendekatan kewilayahan populer untuk perencanaan pengembangan wilayah dan perancangan wilayah merupakan aspek penting dalam geografi.

Konsep area yang dibicarakan di sini, disebutkan dengan istilah place yaitu tempat. Dikemukakan bahwa place dapat berupa sudut suatu ruangan, dapat pula berupa suatu lapangan sepakbola, dapat pula berupa pantai. Dikernukakan pula sebuah region dapat terdiri dari sejumlah places. Konsep aksesibilitas sering digunakan sebagai kata sinonim dari lokasi relatif. Aksesibilitas adalah kesempatan atau potensi suatu lokasi untuk dapat berhubungan dengan lokasi-lokasi lain. Lokasi adalah sebuah area atau tempat yang menunjukkan keberadaan benda atau objek pada umumnya divisualisasikan berupa titik dalam sistim skala geometric pada suatu peta. Dalam arti sempit istilah tersebut disamakan artinya (equivalent) dengan tapak (site), sedangkan dalam konteks yang lebih luas menggambarkan situasi bahkan juga wilayah (region). Tapak merupakan suatu lokasi absolut yang menjadi tempat aktivitas atau bangunan -:idirikan. Tapak memberikan indikasi yang berhubungan dıngan lingkungan fisis setempat. Dalam studi geografi dibedakan pengertian lokasi absolut dengan relatif. Lokasi absolut merupakan lokasi yang eksak, pasti, ditunjukkan/divisualisasikan dengan sistim koordinat keruangan pada permukaan bumi dalam bentuk garis lintang dan garis bujur. Adapun lokasi relatif (untuk bagian berikutnya disebut dengan aksesibilitas) adalah 
cara untuk memberikan makna pada suatu lokasi mengenai kelebihan ataupun kekurangan dibandingkan dengan lokasi-lokasi yang lain.

Lima tema geografi yakni location, place, human environment interactions, movement, dan regions. Kelima tema ini digunakan sebagai kerangka kerja untuk kajian geografi yang sebenarnya sudah mulai dipopulerkan sejak tahun 1994. Dalam mempelajari fenomena muka bumi dengan perspektif geografi, lima tema ini menjadi pedoman standard mulai dari perencanaan, pemecahan masalah hingga implikasi yang dapat disarankan oleh ahli-ahli geografi.

Tema lokasi untuk menjawab pertanyaan dimana suatu fenomena bagian muka bumi dikaji. Lokasi meliputi lokasi absolut yang dikaitkan dengan garis lintang dan garis bujur, keberadaanya dimuka bumi cenderung tetap sepanjang waktu. Lokasi relatif cenderung berubah-ubah dalam periode waktu tertentu. Dalam studi geografi lokasi relatif mempunyai makna yang lebih penting dibandingkan dengan lokasi absolut. Pada lokasi relatif nilai-nilainya selalu diperbandingkan ataupun dihubungkan dengan lokasi dari objek yang sejenis ataupun objek-objek lain di tempat berbeda. Hal ini berarti bahwa lokasi relatif mempunyai makna langsung dengan jarak. Jarak mempunyai tiga dimensi ukuran yaitu: pertama, jarak geometris dengan satuan ukuran kilometer, mil, yard, dan lain sebagainya. Kedua, jarak diukur dari segi dimensi waktu, misalnya, menit, jam, hari, minggu dan lain-lain. Ketiga, jarak diukur dari dimensi ongkos, yaitu biaya yang harus dikeluarkan untuk memindahkan barang per-kesatuan volume atau berat; demikian pula untuk memindahkan orang dari tempat ke tempat lainnya. Dengan adanya perbaikan saran dan prasarana transportasi, misalnya peningkatan kualitas jalan ataupun pembuatan jalan tembus serta munculnya alat-alat angkutan baru seperti, bus, truk, colt, serta alat angkutan lain, menimbulkan perubahan jarak dalam arti relatif dari lokasi-lokasi dihubungkan oleh jalur-jalur perhubungan itu.

Tema tempat terkait antara lain dengan kajian ada apa, mengapa, dan bagaimana dengan tempat tersebut. Dikaitkan dengan karakteristik manusia dan fisik sehingga menimbulkan satu fenomena tertentu. Karakteristik fisık termasuk di dalamnya mengenai pegunungan, dataran tinggi, sungai, tanah, batuan, pantai, belantara, dataran rendah disamping adanya karakteristik manusia. Karakteristik manusia meliputi ide dan 
gagasan yang memuncuikan fenomena tertentu dikaitkan dengan karakteristik fisik di depan. Karakteristik manusia ini muncul sebagai fenomeria perubahan lingkungan, munculnya bangunan/gedung-gedung, fasilitas jalan, pemenuhan kebutuhan papan, pangan, dan sandang serta kebutuhan lain. Sesuai dengan cipta rasa dan karsa manusia dengan kajian tempat ini muncul pengalaman, kemampuan manusia, untuk mensikapi karakteristik fisik sesuai dengan perkembangan peradapan umat manusia. Tempat yang didominasi dengan cipta rasa karsa yang berbeda akan memunculkan perilaku, persepsi, penilaian tehiadap karakteristik fisik yang berbeda.

Tema human environmental interaction dalam tema ini mengandung konsep manusia melakukan adaptasi terhadap lingkungan, manusia melakukan modifikasi terhadap lingkungan dan manusia tergantung pada lingkungan. Dalam tema human environmental interaction sejalan dengan faham geografi yang telah berkembang selama ini yakni deterministik, posibilistik dan probabilistik. Faham tentang kedudukan manusia terhadap alam yakni manusia dipengaruhi/ditentukan oleh alam dalam kehidupannya, manusia mempengaruhi/mensiasati alam untuk kehidupannya, dan manusia dengan alam terdapat kesalingan sehingga ada ketergantungan, ada interaksi, ada interelasi antara manusia dengan alam dalam menciptakan keselarasan muka bumi.

Tema movement meliputi adanya perpindahan gagasan atau ide, perpindahan barang, dan perpindahan manusia. Dalam era global perpindahan gagasan, barang, dan manusia tanpa mengenal batas ruang dan waktu sehingga memunculkan persamaan dan perbedaan tentang fenomena muka bumi, dalam rangka aktualisasi manusia memenuhi kebutuhan pangan, papan, sandang, dan informasi.

Tema region merupakan unit dasar dalam kajian geografi yeng saat ini sebagai pedoman dalam analisa geografi yang menjadi ciri pendekatan geografi sebagai ilmu. Untuk melihat wilayah dalam kajian fenomena muka bumi, geografi mendasarkan pada formal regions, functional regions, dan vernacular regions. Wilayah berdasarkan pemerintahan, administratif, batas wilayah fisik mendasarkan pada kenampakan fisik, berdasarkan pada fungsi tertentu seperti pelayanan komunikasi, pelayanan ekonomi, pelayanan sosial serta berdasarkan persepsi yang diciptakan manusia seperti arah atau tujuan tertentu bagian barat, timur, sebelah selatan, dan 
lain-lain. Tema-tema geografi dapat dijadikan kerangka kerja dalam setiap kajian fenomena muka bumi dengan bingkai geografi. Dinamika perubahan tema-tema ini akan terus berkembang sesuai dengan perkembangan ilmu dan semakin kompleksnya permasalahan tentang fenomena geografi.

\section{Penutup}

Geografi manusia merupakan cabang ilmu geografi, memiliki obyek material yang menekankan tentang perilaku dan aktifitas manusia di muka bumi. Tantangan yang diperlukan adalah meningkatkan kinerja para tokoh dalam institusi yang kondusif agar geografi manusia dapat berperan untuk menjawab permasalahan terkait dengan apa, dimana, kenapa, dan bagaimana relasi manusia dengan alam dengan fokus kajian tentang manusia dalam ruang dan tempat di muka bumi masa lalu, masa sekarang, dan masa depan.

\section{Daftar Pustaka}

Hagget, Peter. 1984. Geography: A Modern Synthesis. New York: Harper and Row.

Johnstun, R.J. 2000. Philosophy and Human Geography: An Introduction to Comtemporary Approach. London: Edward Arnold.

Johnston, R.J. 2000. The Dictionary of Human Gegraphy. Oxford: Brasil Blackwell.

Kitchin Rob and Nicholas J. Tate. 2000. Conducting Research in Human Geography: Theory, Methodology and Practice. Singapore: Addison Wesley Longman, Singapore (Pte) L.td.

Peet, Richard. 1998. Modern Geographycal Thought. USA: Blackwell Publisher.

Suharyono. 1994. Pengantar Filsafat Geografi. Jakarta: Dirjen Pendidikan Tinggi Depdiknas.

Sutanto. 2000. Geografi dan Permasalahannya di Indonesia. Majalah Geosfer Vol. 2 No. $1 \mathrm{hlm} 34$ - 42. Yogyakarta. 
II Ada Apa dengan Geografi Manusia?

Suriasumantri. 1990. Filsafat llmu Sebuah Pengantar Populer, Jakarta: Pustaka Sinar Harapan.

Yunus, Hadi Sabari. 2005. Metode Penelitian Geografi Manusia, Pendekatan dan Permasalahan Penelitian. Seminar Pendekatan dan Metode Penelitian Geografi tanggal 28 April 2005. Yogyakarta: Fakultas Geografi UGM. 